\title{
The Post-Modification of Noun Phrase: Types and Distributions on Abstracts of Local and International Journals
}

\section{(Posmodifikasi Frase Nomina: Tipe dan Distribusi pada Abstrak Jurnal Lokal dan Internasional)}

\author{
Shanty A. Y. P. S. Duwila \\ Ari Astutik \\ Fakultas Bahasa dan Sastra - Universitas Wijaya Putra \\ Jalan Raya Benowo 1-3, Surabaya \\ Tel.: +62 (31) 7404404 \\ Surel: shantiduwila@uwp.ac.id
}

Diterima: 10 Desember 2019 Direvisi: 15 Juli 2020 Disetujui: 20 Juli 2020

\begin{abstract}
Abstrak
Berfokus pada kompleksitas frase nomina dengan posmodifikasi tunggal dan ganda dalam teks akademik, penelitian ini berlandaskan pada metodologi klasifikasi posmodifikasi Frase Nomina Berlage (2014) tunggal dan ganda untuk menyelidiki jenis dan distribusi frase nomina pada 15 abstrak jurnal lokal terakreditasi dan 15 jurnal internasional terindeks oleh Scopus. Subjek, objek, dan pelengkap diberi kode secara manual dan kemudian direduksi pada frasa kata benda. Temuan mengungkapkan bahwa kedua kelompok penulis sangat bergantung pada frasa kata benda yang melibatkan frasa preposisional dalam modifikasi pos tunggal dan frasa kata benda yang melibatkan frasa preposisi dan koordinasi dalam frase nomina dengan posmodifikasi ganda. Temuan ini dapat memberikan kontribusi pada guru dan pengembang materi bahasa Inggris untuk memberikan informasi dan materi tentang posmodifikasi dari frase nomina sehingga nantinya dapat digunakan dalam penulisan akademik.
\end{abstract}

Kata kunci: frasa nomina, jurnal lokal, jurnal internasional, posmodifikasi

\begin{abstract}
Focusing on single and multiple post-modification of noun phrase complexity in academic writing, this study adopted Berlage's (2014) types of single and multiple postmodification of noun phrase to investigate the types and distributionof noun phrase on 15 abstracts of accredited local journal and 15 international journal indexed by Scopus. Subjects, objects, and complements are coded manually and then extracted for noun phrases. The findings revealed that both groups of writers heavily relied on noun phrase involving prepositional phrase in single-post modification and noun phrase involving prepositional phrase(s) and coordination(s) in multiple-post modification. This finding may give contribution to EFL teachers and material developers in order to provide information and materials about NP post modifiers that can be used in academic writing.
\end{abstract}

Keywords: international journals, local Journals, noun phrase, post-modification 


\section{INTRODUCTION}

Indonesian government expects to develop a "world class" education system by 2025 . This issue is deliberately addressed to higher educations that have responsibility to complete the project. One big step taken by the government is the emergence of The Ministry of Research and Technology and Higher Education decree No. 20, the year 2017 about research and research article publication. The Ministry reminds universities in Indonesia to produce their research products and research articles published in reputable academic journals. This decree also obliges professors and lecturers to publish their work in reputable journals. Obtaining a research project that is published in an approved journal has benefits for both the authors and the host institutions. The publication matters in order to improve and prove the quality of their students and the institutions as well. It is through publication that the works including its theoretical and practical contributions are disseminated to others.

Nevertheless, publishing a journal article for Indonesian students is challenging since English is a foreign language in this country. There are some internal factors need to be considered by Indonesian writers, such as: linguistic competence, native language interference, motivation, and reading habits of the learners (Hidayati 2018). From those four factors, linguistic competence and native language interference are considered the most complicated factors since these components affect each other. Before writing an academic text in foreign language, a writer should understand sentence or phrase structures of the target language. One of those structures which somehow prominent to be considered is structures of Noun Phrase (NP).

$\mathrm{NP}$ is a salient language feature in the academic written discourse since all core sentences consist of NP and Verb Phrase (VP) components. Biber and Gray (2011) explained that Nominal structures with phrasal modification are more frequent to be found at academic discourses than those at fictions and news report. In line with this finding, Parkinson and Musgrave (2014) found that proficient writers used higher-level types of noun modifiers on their research articles than those less proficient writers. A word group with a noun or pronoun as its head can be described as the English noun phrase. It can therefore comprise more than one word and/or even a clause, where the function of the head and its dependents emphasize the interactions within the elements in the noun phrase. A complex noun phrase contains the head (a word that could stand alone as a simple noun phrase) and modification such as; determiner, a pre-modifier and a post-modifier. Pre-modifiers occur before the head, whereas post-modifiers come after the head. Pre-modifiers are often adjectives, but other nouns can also modify the head. Post-modifiers can consist of relative clauses, non-finite clauses, prepositional phrases, adverbs, adjectives and noun phrases in apposition.

The present study will be based on Berlage (2013) classification of post-modifiers of Noun Phrase. On her research, she used methodology in categorizing noun phrases based on the modifiers. She focused her research on post-modifiers since the postmodifiers of English is more complex than those of pre-modifiers. The post-modifiers of NP can be divided into two big areas single and multiple post-modifications. The difference between the two is a number of syntactic nodes followed the head. Table 1 and Table 2 present variables of NP. 
Table 1. Single Post-Modification (Berlage 2013:44)

\begin{tabular}{cc}
\hline Type & Single Post-Modification \\
\hline 1 & Non-Postmodified NPs \\
\hline 2 & Coordinated NPs \\
\hline 3 & NP + PP \\
\hline 4 & NP + AP \\
\hline 5 & Gerundial Constructions \\
\hline 6 & NP + Non-Finite Clause \\
\hline 7 & NP + Finite Relative Clause \\
\hline 9 & Free WH Clause \\
\hline
\end{tabular}

We found that the variables of NP with single-post modification in Table 1 for variable type 1 do not represent as post-modification. The pattern on that variable is against the definition of what post-modification is. It also occurs for Type 1 on multiple postmodification. Later, for the need of analysis we omit the first category.

Table 2. Multiple Post-modification (Berlage 2013:53)

\begin{tabular}{cl}
\hline Type & \multicolumn{1}{c}{ Multiple Post-Modification } \\
\hline 1 & Non-postmodified NPs \\
\hline 2 & NPs involving coordinations and/or PPs \\
\hline 3 & NPs involving (non-finite) supplements \\
\hline 4 & $\begin{array}{l}\text { Gerundial constructions involving other structures and NPs involving } \\
\text { gerundial constructions and/or non-finite clauses }\end{array}$ \\
\hline 5 & NPs involving finite clauses \\
\hline
\end{tabular}

A number of studies have been conducted by some researchers such as Biber and Gray (2010), Haan (2016), Parkinson and Musgrave (2014), Adebileje (2016), Li (2017), and Akinlotan (2019) in analyzing NP in various discourses from various aspects. Biber and Gray (2010) discussed structural NP in academic proses. They found that embedded phrases were found more frequently rather than dependent clauses. The use of appositive NPs occur more complex to give detail information. Parkinson and Musgrave (2014) studied development of noun phrase complexity in the writing of English for Academic Purposes students. They found that the less proficient group relied heavily on attributive adjectives and a modifier hypothesized. Meanwhile, the more proficient group used modifiers which was much closer to published frequencies for academic prose. While, Adebileje (2016) used two novels from different authors to analyze NP(s) form and function. She found that there is a relation between the forms, the meanings, and the intentions of the two authors. For a novel which has teenagers readers, the novel used more simple NP(s) forms while the sophisticated novel which needs critical readers, the used of $\mathrm{NP}(\mathrm{s})$ is more varied and more complex. Haan (2016) analyzed the used of $\mathrm{N}(\mathrm{s})$ and $\mathrm{NP}(\mathrm{s})$ in advanced Dutch EFL writing. The finding has shown that the NP distribution and NP patterns indicate written EFL proficiency level. It is also explained that an appropriate expository style is characterized by more complex NPs, PPs, words from the Academic Word List, and a relatively low lexical density.

The latest research conducted by Li (2017) compared noun phrase complexity in two corpora: one is a corpus of MA dissertations written by Chinese EFL students and the other comprises published research articles in applied linguistics journals. The finding 
showed that the use of NP in research articles is more complex than that of in MA dissertations on all three NP complexity measures: mean length of clause; complex nominal per T-unit; and complex nominal per clause. Another recent research conducted by Akinlotan (2019) and Xu (2019) who analyzed syntactic complexity of NP in academic discourses used by native and non-native English speakers. The similar findings of both researchers are the native speakers used more complex structure of NP(s) through phrasal elaboration than clausal coordination and subordination. Comparing native speaker and non-native speaker performances provides valuable information for EFL teachers and course material developers (Hinkel and Fotos 2002).

The present study differs particularly in the area of the source of data. This research compared the used of NP in accredited local journals which are written by Indonesian scholars and Scopus indexed journal. The reason why we choose Scopus indexed journals is we assume that any articles published in Scopus journals are internationally readable and accepted. Considering the aforementioned purpose, this study attempts to find out the types and distribution of post-modifiers of NP from both abstracts journals and provide with a brief description. Practically this study will give benefit for EFL teachers who teach academic writing. By noticing the types and distribution of NP on abstract Local and International journal, teachers will be more aware and know what to be highlighted, emphasized, and exposed to their students particularly when teaching NP to meet academic writing purposes.

\section{METHOD}

This present study uses a descriptive qualitative research. The sources of data are fifteen abstract accredited local journals and fifteen abstracts of Scopus journals. The first source of data is taken from Mozaik Humaniora published by Universitas Airlangga and Humaniora published by Universitas Gadjah Mada. The second one is taken from Sage Publication. In order to obtain validity of the results, the abstracts used must meet the criteria: consist of 150-200 words, cover social areas, and be written in 2016-2018.

To analyze the data, we use qualitative content analysis. According to Holsti, content analysis is any research technique for making inferences by systematically and objectively identifying specified characteristics of messages (1968:601 cited in Titscher et al. 2000:57). In line with the present study, we try to analyze the patterns of NP written in local and international abstract journals. We follow three stages of data analysis procedures: Identification, Categorizing, and Explanation. The procedure of data analysis, then, is adjusted with the need of the research. The procedure can be seen as the following:

\section{Identification}

The purpose of identification is to find out of NP(s) in each sentence. There are three steps in identifying the NP units:

a. Classifying subjects and objects in each sentence. In this step, we try to extract NP(s) from subject and object positions and then continue by classifying NP (s) based on post modifiers. So that in this step the data we got are Subjects and Objects with Single and Multiple Post Modification

b. Coding

The coding is in fact the formal representation of analytical thinking which is necessary for the interpretation. For that purpose, it will use a combination abbreviation of keys words which were called descriptive codes 
(Miles and Huberman, 1994:57). We code the data as the following: 1) SSPM_LJ1.1 reads Subject Single Post Modifier_Local Journal 1. First Sentence. 2) SMPM_LJ1.2 reads Subject Multiple Post Modifier_Local Journal 1.Second Sentence. 3) SSPM_SJ1.1 reads Subject Single Post Modifier_Sage Journal 1. First Sentence. 4) SMPM_SJ1.2 reads Subject Multiple Post Modifier_Sage Journal 1.Second Sentence. 5) OSPM_LJ1.1 reads Object Single Post Modifier_Local Journal 1. First Sentence. 6) OMPM_LJ1.1 reads Object Multiple Post Modifier_Local Journal 1. First Sentence. 7) OSPM_SJ1.1 reads Object Single Post Modifier_Sage Journal 1. First Sentence. 8). OMPM_SJ1.1 reads Object Multiple Post Modifier_Sage Journal 1. First Sentence. 9) etc.

\section{Categorizing}

After coding all the data, in this step we categorizing the extracted data based on types of single and post modifiers of NP. The following are the categories of post modifiers of NP adapted from (Berlage 2013)

Table 3. Single Post-Modification

\begin{tabular}{cll}
\hline Type & Single Post-Modification & \multicolumn{1}{c}{ Examples } \\
\hline 1 & Coordinated NP(s) & Destruction and exploitation \\
\hline 2 & NP+PP(s) & Women in uneasy situation \\
\hline 3 & NP+AP & The day suitable \\
\hline 4 & Gerundial constructions & Using the equivalence method \\
\hline 6 & NP + non-finite clause & The way youngsters involved in the community \\
\hline 7 & Free wh-clause & $\begin{array}{l}\text { The current social context which involves the recent } \\
\text { situation }\end{array}$ \\
\hline 8 & NP + that-clause & $\begin{array}{l}\text { that the majority of popular culture has a negative impact } \\
\text { effective }\end{array}$ \\
\hline
\end{tabular}

Table 4. Multiple Post-Modification

\begin{tabular}{cll}
\hline Type & Multiple Post-Modification & \multicolumn{1}{c}{ Example } \\
\hline 1 & $\begin{array}{l}\text { NPs involving } \\
\text { coordination(s) and PPs }\end{array}$ & $\begin{array}{l}\text { Psilocybin-occasioned mystical-type experience and rates of } \\
\text { meditation/spiritual practices }\end{array}$ \\
\hline 2 & $\begin{array}{l}\text { NPs involving PPs and } \\
\text { coordination(s) }\end{array}$ & $\begin{array}{l}\text { Long-standing interest to researchers in management and } \\
\text { related disciplines }\end{array}$ \\
\hline 3 & $\begin{array}{l}\text { NPs involving PPs and } \\
\text { Clause }\end{array}$ & $\begin{array}{l}\text { An agenda for future management research that addresses } \\
\text { both unresolved debates }\end{array}$ \\
\hline 4 & $\begin{array}{l}\text { Gerundial constructions } \\
\text { involving other structures }\end{array}$ & $\begin{array}{l}\text { Manipulating the procedure and physical artifacts available } \\
\text { for performing the towel-changing routine at a hotel }\end{array}$ \\
\hline
\end{tabular}

\section{Explanation}

The explanation of the distribution and types of NP(s) either for local and international abstract journal articles is provided by describing similarities and differences as well as factors influencing.

\section{RESULTS AND DISCUSSION}

After analyzing the data carefully based on the procedure described above, the following is the detailed information of the types and distribution of $\mathrm{NP}(\mathrm{s})$ in local and international journals. 


\section{Noun Phrase with Single Post-Modification}

Table 3. Types and Distribution of NP for Single Post-Modification of Subject and Object/Complement

\begin{tabular}{clcccc}
\hline \multirow{2}{*}{ Type } & \multirow{2}{*}{ Single Post-Modification } & \multicolumn{2}{c}{$\begin{array}{c}\text { Subject } \\
(\%)\end{array}$} & \multicolumn{2}{c}{$\begin{array}{c}\text { Object/Complement } \\
(\%)\end{array}$} \\
\cline { 3 - 6 } & & LJ & SJ & LJ & SJ \\
\hline 1 & Coordinated NP(s) & 4 & 2 & 11 & 5 \\
\hline 2 & NP+PP(s) & 24 & 32 & 17 & 14 \\
\hline 3 & NP+AP & 0 & 0 & 0 & 0 \\
\hline 4 & Gerundial constructions & 1 & 0 & 2 & 0 \\
\hline 5 & NP + non-finite clause & 10 & 3 & 10 & 3 \\
\hline 6 & NP + finite relative clause & 0 & 0 & 5 & 1 \\
\hline 7 & Free wh-clause & 1 & 0 & 17 & 21 \\
\hline 8 & NP + that-clause & 1 & 1 & 4 & 2 \\
\hline & Total & 41 & 38 & 66 & 44 \\
\hline
\end{tabular}

The distribution of subjects on single post-modification does not equally spread. There is only one type of the modifier which is mostly dominant. Both Indonesian writers and Sage journals' writers use the patterns. There is no significance difference between the percentages of this type. It means that NP + PP (s) is the most suitable pattern to write in academic discourse. No writers from local and international journal articles who use patterns on type 3, type 6 and type 8 . Only $1 \%$ of local writers use gerundial constructions and free WH clause while no writers of international journals use these patterns. Type 1, Coordinated NP (s), is the least used by both group writers. The significant difference can be seen on the distribution of single-post modification on type 5. Most of Indonesian writers used this pattern in subject area while for International writers only $3 \%$.

The distribution of the patterns of single post-modification is equal except for two patterns, type 3 and 4 . Neither both group uses NP+AP, and gerundial construction is not used in object position by International writers. The most commonly used patterns in object position are type 2 and 7. The highest percentage is pattern on type 7. Mostly international writers used this pattern in object position while Indonesian writers used $\mathrm{NP}+\mathrm{PP}$ and NP+WH-clause. Both types reach the same score $17 \%$.

\section{Noun Phrase with Multiple Post-Modification}

Table 4. Types and Distribution of NP for Multiple Post-Modification of Subject and Object/Complement

\begin{tabular}{cllccc}
\hline \multirow{2}{*}{ Type } & \multicolumn{2}{c}{ Multiple Post-Modification } & \multicolumn{2}{c}{ Subject } & \multicolumn{2}{c}{ Object/Complement } \\
\cline { 2 - 6 } 1 & $\begin{array}{l}\text { NPs involving coordination(s) } \\
\text { and/or PPs }\end{array}$ & 1 & 1 & 6 & SJ \\
\hline 2 & $\begin{array}{l}\text { NPs involving PPs and } \\
\text { coordination(s) }\end{array}$ & 6 & 8 & 17 & 23 \\
\hline 3 & NPs involving PPs and Clause & 2 & 0 & 8 & 8 \\
\hline 4 & $\begin{array}{l}\text { Gerundial constructions } \\
\text { involving other structures }\end{array}$ & 0 & 0 & 8 & 5 \\
\hline & Total & 9 & 9 & 39 & 42 \\
\hline
\end{tabular}


Based on the Table 4 above, the distribution of NP with multiple post-modification mostly occurs at object positions. In total is $1: 5$. The most commonly used pattern in subject position is type 2 . Meanwhile type 3 and 4 are the least used. No writer from both groups use gerundial constructions involving other structure. Writers from International journals also do not use pattern type 3 while there is only $2 \%$ of Indonesian writers who use it. The NP(s) in object or complement position is more vary and equally spreading on each type. Pattern that the most commonly used is NPs involving PPs and coordination(s). It is followed by type 3, 1, 5. Both group use type 3 and 5 with the same percentages, $6 \%$ and $8 \%$.

Considering the finding of types and distribution of single and multiple postmodification of NP on Table 3 and Table 4, shows the extent to which the two groups of writers in our two datasets rely on the same noun modifiers. On Table 3 shows, that both group use NP+PP on subject and object/complement position.in addition, both group also use the same pattern NPs involving PPs and coordination(s) as presented on Table 4. Post-modifying prepositional phrases made up a greater proportion of the modifiers used in both journals. This finding supports Biber's research which explained that NP+PP modifiers are less frequently used in conversation than in academic discourse, with only around 12 post-modifying prepositional phrases per 1000 words in conversation (Biber et al., 1999:606).

\section{CONCLUSION}

In general, there is no significant difference between the percentages of the use either single or multiple post modification NP. It indicates that the quality of accredited local journals is equal to that of Sage Journals. However, there are some points to be highlighted. First, both writers produced all types of post-modifiers except NP+AP and Gerundial Construction. NP+AP, NP + Finite relative clause, Free WH, and Gerundial construction as single post-modification never occur in International journal articles. Second, the most common used patterns by International writers are Free WH-Clause and NP+PPs for single post-modification and NPs involving PPs+ Coordination(s). This finding may give contribution to EFL teachers and material developers in order to provide information and materials about NP post modifiers that can be used in academic writing.

\section{ACKNOWLEDGEMENT}

We would like to thank to Kemenristek Dikti for a financial support of the research through the "Penelitian Dosen Pemula" grant.

\section{REFERENCES}

Adebileje, Adebola. 2016. "Forms and Functions of the English Noun Phrase in Selected Nigerian Texts." IOSR Journal Of Humanities And Social Science 21 (2): 4549. doi: 10.9790/0837-21214549.

Akinlotan, Mayowa. 2019. "Noun Phrase Complexity in Nigerian English: Syntactic Function and Length Outweigh Genre in Predicting Noun Phrase Complexity." English Today 33 (3):31-38. doi: 10.1017/S0266078416000626.

Berlage, Eva. 2013. Noun Phrase Complexity in English. doi: 


\subsection{7/CBO9781139057684.}

Biber, D. E. \& B. Gray. 2011. "Grammatical Change in the Noun Phrase: the Influence of Written Language Use." English Language and Linguistics 15 (2):223-250. doi: org/10.1017/S1360674311000025.

Biber, D., S. Johansson, G. Leech, S. Conrad, \& E. Finegan. 1999. Longman Grammar of Spoken and Written English. Edinburgh: Pearson Education Limited.

Haan, Pieter De. 2016. "Nouns and Noun Phrases in Advanced Dutch EFL Writing: From Quantitative to Qualitative Longitudinal Data Analysis." In Studies in Learner Corpus Linguistics. Research and Applications for Foreign Language Teaching and Assessment, edited by Erik Castello, Katherine Ackerley, Francesca Coccetta. Bern, Berlin, Bruxelles, Frankfurt am Main, New York, Oxford, Wien: Peter Lang.

Hidayati, Kuni Hikmah. 2018. "Teaching Writing to EFL Learners : An Investigation of Challenges Confronted by Indonesian Teachers." Langkawi: Journal of the Association for Arabic and English 4 (1):21-31.

Hinkel, Eli and Sandra Fotos. 2002. "New Perspectives on Grammar Teaching in Second Language Classrooms.” ESL E⿱ Applied Linguistics Professional Series. doi: $10.2307 / 3588337$.

Li, Lan. 2016. "Noun Phrase Complexity in EFL Academic Writing: A Corpus-Based Study of The Journal of Postgraduate Academic Writing." The Journal of Asia TEFL 13 (1): 48-65. doi: 10.18823/asiatefl.2016.13.1.1.48.

Miles, M. B. \& A. M. Huberman. 1994. Qualitative Data Analysis: An Expanded Sourcebook. Thousand Oaks, London, New Delhi: Sage Publications.

Parkinson, Jean and Jill Musgrave. 2014. "Development of Noun Phrase Complexity in the Writing of English for Academic Purposes Students." Journal of English for Academic Purposes 14:48-59. doi: 10.1016/j.jeap.2013.12.001.

Titscher, Stefan, Michael Meyer, Ruth Wodak, and Eva Vetter. 2000. Methods of Text and Discourse Analysis. London: SAGE Publication.

Xu, Lirong. 2019. "Noun Phrase Complexity in Integrated Writing Produced by Advanced Chinese EFL Learners." Papers in Language Testing and Assessment 8 (1):31-51. 